\title{
The Law Interpretation and its Role \\ in Legislative Implementation \\ of Philosopho-legal Conceptions \\ of the Natural Law in the Period of Modern Era
}

\author{
Yulia V. Nedilko* \\ Kuban State Agrarian University \\ 13 Kalinin Str., Krasnodar, 350044, Russia
}

Received 08.02.2016, received in revised form 16.04.2016, accepted 26.05.2016

\begin{abstract}
This article investigates ways and methods of solving problems associated with the law interpretation, proposed by the European legal scholars in the period of Modern Era. The author states that researchers have advocated the formation of legislation and its interpretation which bases on the principles of natural justice; gives examples of problems in the legislation and its interpretation in Europe of the Modern Era period. The work also emphasizes the influence of European supporters of the natural law theory on the resolution of legal issues through the law interpretation. The extension of views on the natural law contributes to the fact that the European legislation and its interpretation begin to be based on the principles of justice and humanity.
\end{abstract}

Keywords: theory of natural law, interpretation of legal norms, Modern Era, "Platonic cassation", European jurists, legal controversy, principle of justice, principle of humanity.

DOI: 10.17516/1997-1370-2016-9-8-1849-1856.

Research area: law.

The problems of law interpretation have often drawn attention of many scientists (Bertrall, 2014). Still, the analysis of its impact on the legislation and its enforcement within different historical epochs remains insufficient.

In this article we will try to bridge in some way the gap by focusing on theoretical studies in the law interpretation made by supporters of the natural law doctrine within the period of Modern Era in Western Europe and on their implementation.

In the history of state and law as well as in political and legal theories, the Modern Era is characterized by an active establishment and development of the major law schools. There was a final approval of the legislation as the main source of law, which, in its turn, was gradually seeking to embody the natural law attitudes.

It is an interesting point here, that the reason for the natural law development should be considered as the result of resistance of "German legal awareness to Roman Law enforcement" (Erlikh, 2011: 418), to its massiveness and unwieldiness: if Romans deduced general principles and provisions from the content of

(C) Siberian Federal University. All rights reserved

* Corresponding author E-mail address: jvna@list.ru 
numerous legal norms, then members of the natural law school rather chose the opposite tack, i.e. first, they defined basic principles and values and by following them formed and interpreted the legislation.

One of the most prominent supporters of this theory was Hugo Grotius, a Dutch scientist. In his famous treatise "On the Law of War and Peace: Three books" he touched upon the issue of law interpretation. Thus, he emphasized, that in that case the interpretation of legal norms according to the requirement of natural law is more preferable (Grotius, 1994: 30). One of the grounds for the natural law is represented by the idea of justice. By developing this point, Grotius pays particular attention to injustice and ranks all the things that are contrary enough to the reasonable and sociable nature of a person. On the basis of this statement, the natural law interpretation should be based on the principle of justice, and, consequently, be consistent with the reasonable and social human character.

The importance of this principle was marked also by Jean-Jacques Rousseau, a French enlightener. Given that a law maker in his work should follow the principle of justice, so this principle should also be applied by an interpreter under the meaning translation. In Rousseau's perception, the laws are acts of our common will. Thus, their interpretation should be made basing not on interests of the person, but on one of the whole society. As the philosopher sees it, only the law maker can better than anyone else interpret laws and know how they should be effectively enforced (Rousseau, 1969: 118). In this way, Rousseau advocates an authentic interpretation of the legal norms.

The same point of view was supported by B. Spinoza. By emphasizing his adherence to the natural law and allowing disregard of the law, which conflicted with his ideas, the philosopher thinks, that the law interpreter can be just the subject, who wields the supreme power, and only that person can resolve the problem of conflict or consistency of a norm to the natural law and cope with the issue of violation or expression of the common good. For this reason, the decisionmaking right on non-application of the law, which contradicts the natural law requirements, belongs only to supreme authorities (Spinoza, 1957: 567).

However, as the researches show, understanding of the common good and virtue differs depending on nations, countries and epochs. This fact was mentioned by Voltaire. In seeking to identify a common rule, Voltaire notes, the commonwealth should be the only measure of moral good and evil, for the sake of which people must correct their own ideas of right and wrong.

The educator also stressed the problem of legal contradictions: "Most laws contradict themselves so evidently, that it has a very little relevance what laws regulate the state, indeed, a great importance has the law implementation" (Voltaire, 1989: 268). Obviously, this problem is matched by the issue of government orders implementation reflected in the conflicts-oflaw rule, the solution of which is impossible without a correct interpretation. According to the abovementioned Voltaire's ideas, such selection of choice and interpretation is considered to be right what would provide the law implementation for the public benefit.

Within the theoretical discourse of Montesquieu, one can also see the interpretation rules, enabling, as he sees it, the law "spirit" to be correctly understood. He wrote about a necessity for the law to be fitted with the nature and principles of the established government (or the one under establishment), physical features of the state, national life-style, degree of its freedom, religion, social customs and habits caused by the circumstances of its genesis (Montesquieu, 1955: 168). 
It makes sense, that acceptance of such points as a common rule both for the law-makers and law-enforcers, significantly facilitates the work of interpreters, since within an ambiguity or non-transparency the content of norms makes it possible to formulate or choose such an interpretation that would meet all the mentioned points, and, thus, would allow implementation of the law-maker's real will.

We can say, that Montesquieu gives a priority to literal interpretation, since, as he says, "if the trial bench should not remain unchanged, then its sentences must be unchanged, so as to keep them always being able to express the law text" (Montesquieu, 1955: 196).

In "The Spirit of the Laws" Montesquieu states a number of rules for the legal engineering. In his analysis, the laws should be compressed; avoid "going into details", since only then they can serve as a "model of precision"; and besides, they must be written in the direct language: explicit expressions are always easier to be understood, than the subtle ones. The laws must be available for a unified understanding: "The key term is that words in law should evoke in different people one and the same notions.

The law should reflect a common rule: when there is no need in exceptions, limitations or modifications, so it is better to deal without them, since "such details cause new details".

Moreover, the laws should be made for the social benefit and should not give a rise to avoid them.

By expressing a view, that the law contents should be concise and explicit, Montesquieu, nevertheless, was hostile to their loose interpretation, pointing out that the content of court sentences must be written so as they would remain a precise application of the law. The court's subjectivity, as the philosopher claims, is unacceptable; otherwise, "people would have to live without a precise notion of obligations imposed on them by the society" (Montesquieu, 1955: 413).

Therefore, the judicial acts, according to Montesquieu's vision, should be considered merely as the law-enforcement acts, and not as the sources of law.

It should be mentioned that a wide implementation of the legal engineering methods, described by Montesquieu, have also had a great influence on the interpretation. To stretch those words and expressions found in the law with the sense, which is common in a particular state and time, is one of the well-known rules in the modern grammatical interpretation. A simple, comprehensible and lapidary legal style also greatly facilitates understanding of the law meaning. Moreover, in the case of content ambiguity in legal norms, their interpretation reasoned by particular principles and purposes of the law renders a significant assistance. Montesquieu says about the social benefit as such purpose. Thus, as he sees it, the interpreter should prefer the one interpretation that provides actualization of this benefit in a more complete way.

The problems of law interpretation were also addressed by C. Beccaria, though he considered them in so far as they were related to the criminal law. The scientist argues against a distinction between such notions as the "letter" and "spirit" of the law. According to his view, it is dangerous to be guided by the "spirit" of the law, since the human nature is quite fickle, subjected to changes in opinions, to influence of internal and external factors, i.e. to reasonable or bad logics of the judge, to how well his stomach works, to his weaknesses and passions, to his attitude towards a victim. Thus, the guidance by the "spirit" of law, depending on the human character and interests, makes a defendant's destiny conditional on them. In such cases judges do not listen to the "permanent and desperate voice of the law, but go 
by the fallible and changeable interpretation". In this case, a strong adherence to the "letter" of law, as Beccaria claims, has much less disadvantages, than the "spirit' interpretation, since it guarantees personal safety and gives an opportunity to be more careful in inconveniencies caused by illegal behavior (Beccaria, 1995: 81).

Calling the law interpretation as evil, Beccaria notes, that their "darkness", which, namely, makes people call for interpretation, is no less wrong. Due to this fact, the analyst suggests for the law texts a demand for clarity and availability, so for this aim, they must be written in the language acceptable to people. As he grounds, understanding of the legal requirements will reduce the level of crime (Beccaria, 1995: 83). The law ambiguity will "further contribute to laziness and stupidity". That is the reason why a strong and courageous nation should get rid of such disadvantage as uncertainty in the law" (Beccaria, 1995: 208).

The same as Rousseau, Beccaria thought, that the law interpretation should be only authentic, and the literal results of this interpretation should be applied by judges. Thus, a judge, even following the principle of justice, has no right to impose a penalty which is not fixed in the law. Moreover, taking into consideration the gravity of criminal nature of this problem, Beccaria excludes the loose interpretation, since a "more severe sentence" the other that is fixed in the law, can probably be fair, but yet "it is another sentence" (Beccaria, 1995: 69), and thus, it violates the law, that is unacceptable even within the social benefit. Commutation of the sentence fixed in the law is also unacceptable, because, as he claims, judges must be unforgiving and follow only the law text. Mercy, in its turn, is a prerogative of the law-maker - the only person who can translate it within the legal norms (Beccaria, 1995: 246).

In general, $\mathrm{C}$. Beccaria notes that judges are obliged to a literal guidance and not to the law interpretation, on the basis that they are not the law-makers. The judges are aimed at a logical structuring of only one right syllogism, because if there is more than one, it will generate loopholes of uncertainty. The power of interpretation must be given only to a sovereign as a "protector of his nationals' will", since the laws represent "the result of the free will expression" of his contemporaries (Beccaria, 1995: 72).

It worth mentioning, that even in the Modern Era some provisions of the natural law doctrine start to gain setting in the legislation. Though, the necessity of their implementation in the legal norms also had different justifications.

Thus, the desire to apply the principle of humanity can be seen through the example of interpretation in favor of the Inquisition abolishing in France. In that case, O. Nicolas, the Chair of the Dijon Parliament, claimed that torture was not a method to get the truth in the serious crimes; it prevented us from obtaining truthful testimonies, since they "escape" from the offender through the inflicted pain; and it contradicted against the requirement of the "natural equality" and "equity of the common law" (Cheltsov-Bebutov, 1995: 453). The torture was opposed by: Beccaria, Montesquieu who considered, that it "fails to satisfy the nature", and by Voltaire. The latter one even assumed it had been introduced by the thieves, who broke into the house of a miser and having failed to find any treasure, tortured him until he said their place (Voltaire, 1956: 204).

It appears that pursuance of the natural law fixation and researches which understand tortures as being non-corresponded with these perceptions, caused the fact that the torture was officially abolished in France in 1780; it was also confirmed in 1789 by the National Assembly.

The other problem solved in France through the natural law interpretation with regard of the Modern Era legislation, was the issue of necessity in the access of a defense counsel to 
detained persons at the pre-trial investigation. Critics of the norm, which permits the defense at the mentioned stage, reasoned their position by the fact that in this context there was a risk to violate the principle of secrecy of investigation that, in its turn, causes difficulties in the truthseeking. Nevertheless, in the $90 \mathrm{~s}$ of the $19^{\text {th }}$ century, a wide publicity was got by abuses of the French examining magistrates, which lead to the conviction of innocent people. The most wellknown among them was the "Dreyfus affair" on espionage in the high-level military circles of France.

The core of this affair comes down to the following fact. In the beginning of the $90 \mathrm{~s}$ in the $20^{\text {th }}$ century, the French General Staff disclosed a regular disappearing of the secret military documents, which, though, were found soon in their places. Moreover, Colonel Arno, the Director of the Intelligence Agency of France, got a bordereau addressed to German Military Attaché, i.e. a covering letter without dates and signatures, containing a list of the secret military documents sent to the addressee. A sender's handwriting looked similar to Captain A. Dreyfus's one, though, it should be mentioned, not all the experts agreed with that conclusion.

Nevertheless, Dreyfus, by the agreement of the General Staff, was destined to play a victim. During the proceedings the examining magistrate used methods of psychological pressure on the accused. Thus, the judge often burst into a dark room where Dreyfus stayed, and directed a bright light on him. The mass media started an extensive intimidation campaign against him.

Still, despite the pressure, Dreyfus did not plead guilty and in the end of investigation the questionable bordereau coupled with the other two, also controversial letters, which mentioned about "that Jew", still remained the only proof of Dreyfus's guilt. The General Staff officials claimed about other evidences, but they did not show them under the pretext that it would be a disclosure of classified information. The court was finally tilted in favor of Dreyfus's guiltiness with the help of a fake and appointed to the German Ambassador note: "That scoundrel Dreyfus becomes too needy", - that was handed by the investigator in the room where judges were conferring.

Still, after the conviction of Dreyfus, the society started to doubt about his guilt. The newspaper "Matin" published the facsimile that had been stamped in the bordereau. Soon, people understood that the handwriting belonged to Mr. Esterhazy, another officer, who was the spy in truth. This fact was later proved by other documents.

Dreyfus's defense and retrial was advocated by broader French communities, including Emile Zola, Jean Jaures and Anatole France.

The Court of Cassation in France, which reviewed the case in 1899, concluded that the affair had not one, but many fake documents. The note, which was handed to the judges as the ground for conviction, had been showed neither to the accused, nor to his defender at the pretrial investigation. Schwarzkoppen, to whom the bordereau was addressed, announced in the press that he in fact had dealt with Esterhazy. Moreover, the affair-makers considering Schwarzkoppen - a German person-as the author of letters, persuaded him to make a number of cardinal mistakes in the French grammar. As it was revealed later, he was born in Alsace and had a good command of French. This fact finally convinced in forged documents against Dreyfus.

Even the German Government officially declared in "Reichsanzeiger" that it had never dealt with Dreyfus. At the same time, his prosecutors failed to present any other proofs, except those that already had been in the affair. Still, despite these facts, the Court of Cassation also found Dreyfus guilty, but under the mitigating circumstances. 
Nevertheless, Dreyfus was granted a pardon by the President.

The affair was re-examined in the 1903, when the Chamber of Deputies found a letter from General Pellieux, one of Dreyfus's prosecutors, dated on 31 August, 1898 and containing the information about the falsehood in this affair. Having read the controversial case, General Andre, the Minister of War, commented on the necessity of re-investigation. In November, 1903 after Dreyfus's filing of a new claim, the affair was examined once again by the Court of Cassation. As the result, the captain was fully justified (// http://www.rudata.ru/wiki).

A widespread concern in the society and policy caused by this affair, played in favor of interpretation on the need in access of a defense counsel at the pre-trial investigation, as the enforcement of guarantees with regard to rights and freedoms of accused persons; investigation of all the circumstances of the case; presumption of innocence and comprehensive examination of the evidences. Largely due to it, on 8 December, 1897 France finally got the law permitting such access of defense at the pre-trial stage.

The natural law theory of the social contract also allowed giving preference to such an interpretation of the legal norms, which would develop the concept of state sovereignty and democratic ideas. Since the natural law theory was organized around the respect for the rights and human personality, and not around estates, as it had been before, it insisted on interpretation of the existing legal norms according to the principle of individualism. Also in the case of legal norms interpretation, by reference to the same theory, one should be guided by the principle of equality before the law and of freedom for all the members of society.

Still, the legislation and legal precedents of the Modern Era did not always follow this way. Thus, the evaluation of evidence, fixed in the
Civil Procedure Code of France in 1808, gives an opportunity to evaluate different protocols in different ways: those, which proves violation of the common law (i.e. of the norms fixed in the Criminal Law), can be disposed by other evidences; and those, which proves offences set forth in special laws (i.e. made by custom services, forest or field services) - only basing on the evidence of their falsification. Such system makes it possible to form the rule, which disagrees with the principle of free evaluation of evidences, positing that evidences made by authorities or officials are conclusive.

This fact was depicted in an episode of A. France's story "Crainquebille", where the author ironically shows the evaluation of evidences made by the judge. France describes the evaluation of contradictory testimonies of two people belonging to different social classes: the first of them is a policeman, and the other one is Doctor David Matthieu. Yet, he marks the judge's hesitation and doubts and says that "he follows the law too strictly", rather than yields to reasons. Consideration of testimonies leads the judge to the "most arguable conclusions". Instead of evaluating evidences according to their characteristics of "accuracy and truthfulness", the judge puts the power of weapon on the scale of justice, i.e. considers the policeman's testimonies to be more suitable. At the same time, France scathingly remarks, that "when a person, who acts as a witness, is weaponed with a sabre, one should take into consideration the sabre, and not the person", since he deserves to be contempt and can make mistakes", and the sabre "is worthy of any respect and always right". As the judge sees it, if he had found the policeman being wrong, that would have hurt him and contradicted the spirit of law (France, 1936: 251, 254).

Implementation of the theory of national sovereignty developed within the natural law 
can be seen through the fact that a person, found innocent by the juries, cannot be prosecuted for one and the same case. It is stated in the functions of the Court of Cassation of France, regulated by the Procedure Code of 1808 . The most vivid example of the national sovereignty realization in its activity is found in so called "platonic cassation". It means a cassation towards the sentence of acquittal made by the juries, which does not involve its reversal, provided that it has been awarded in a wrong way and will not cause a re-trial relating to the acquitted person, but ends only with its registration of the court that has imposed the wring sentence (Garraud, 1926: 1021). This fact answers only for pointing out violations and wrong interpretations of the law to the corresponding court.

This power was exercised within broader functions of the Court of Cassation in terms of interpretation. It verifies whether the legal norms are interpreted correctly, or whether the court correctly bring the actus reus to the applied criminal law provision, i.e. it makes the same interpretation, but regarding the criminal law. Also, there is a criminal and political function of the Court of Cassation in France, based on overseeing the lower courts and providing the uniformed interpretation and appliance of the law (Cheltsov-Bebutov, 1995: 508). Since so, following the sentence repeal caused by a "pure" cassation (not a "platonic" one), the affair is redirected to the same court, which in the case of re-investigation is obliged to apply all the requirements that have been mentioned by the Court of Cassation (Cheltsov-Bebutov, 1995: 509).

To sum all that has been mentioned up, we can conclude, that many changes introduced in the European legislation have managed to be brought to practice due to the development of the theory of natural law and to the interpretation of its most important provisions by the outstanding philosophers of the Modern Era. That is why the legislation and law enforcement practice have received such principles as legitimacy, humanity, equality of citizens and etc., which, in their turn, have been further developed through the interpretation of corresponding legal norms. It should also be mentioned, that this process continues even at the present time.

\section{References}

Beccaria, C. (1995). O prestupleniiakh i nakazaniiakh [On crimes and punishments]. Moscow.

Bertrall, L. Ross II. (2014). The State as Witness: Windsor, Shelby County, and Judicial Distrust of the Legislative Records, In New York University Law Review, 89 (6); Buy Dominique Ritlend. (2015). The dividing line between delegates and implementing acts: The Court of Justice sidesteps the difficulty in Commission v. Parliament and Council (Biocides), In Common Market Law Review, 52 (1); Candace D. Berg. (2014). Widening the Lane: an Argument for Broader Interpretation of Permissible User under the Driver's Privacy, In Notre Dame Law Review, 90 (2); John David Ohlendorf. (2014). Against Coherence Statutory Interpretation, In Notre Dame Law Review, 90 (2); Victoria F. Nourse. (2012). A Decision Theory of Statutory Interpretation: Legislative History by the Rules, In The Yale Law Journal, 122 (1).

Cheltsov-Bebutov, M.A. (1995). Kurs ugolovno-protsessualnogo prava [Course on the criminal procedure law]. Saint-Petersburg.

Delo Dreifusa [Dreyfus Affair]. Available at:// http://www.rudata.ru/wiki; http://nado.znate.ruD1; // http://dic.academic.ru/dic.nsf/ruwiki/907097.

Erlikh, O. (2011). Osnovopolozhenie sotsiologii prava [Foundation for Legal Sociology], SaintPetersburg. 
France, A. (1936). Skazki i rasskazy [Fairy-tales and stories]. Moscow.

Garraud. (1926). Précis de droit criminel. Paris.

Grotius Hugo de Groot. (1994). Prava voiny i mira: tri knigi, vkotorikh ob'iasniaiutsia estestvennoe pravo i pravo narodov, a takzhe printsipy publichnogo prava [The Law on War and Peace: Three books, explaining the natural law and people's law and the principles of public law]. Moscow; Antologiia mirovoi pravovoi mysli: V 5 tomakh. T. III. Evropa. Amerika, XVII-XXvv [Anthology of the world's law theory: in five volumes. Volume III: Europe and America, 17-20 th centuries]. Moscow.

Montesquieu, Ch. (1955). O dukhe zakonov [On the Spirit of the Laws], In Izbrannie proizvedeniia [Selected papers]. Moscow.

Rousseau, Jean-Jacques. (1969). Ob obshhestvennom dogovore, ili Printsipy politicheskogo prava [The Social contract, or Principles of Political Right], In Rousseau J.J. Traktaty [J.J. Rousseau. Treatises]. Moscow.

Spinoza, B. (1957). Politicheskii traktat [Treatise on policy], In Izbrannie proizvedeniia. T. 2. [Selected papers. Volume II]. Moscow, 567 p.

Voltaire. (1956). Izbrannye proizvedeniia po ugolovnomu pravu i protsessu [Selected papers on the criminal law and procedure]. Moscow.

Voltaire. (1989). Metafizicheskii traktat [Treatise on metaphysics], In Filosofskie sochineniia [Essays on Philosophy]. Moscow, 268 p.

\section{Толкование права и его роль}

в законодательном воплощении

философско-правовых идей

естественного права Нового времени

Ю.В. Недилько

Кубанский государственный аграрный университет Россия, 350044, Краснодар, ул. Калинина, 13

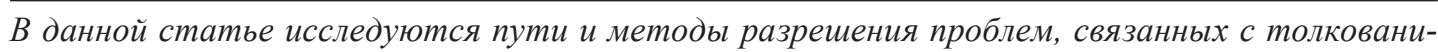
ем права, предложенные европейскими правоведами в период Нового времени. Указывается, что исследователи выступали за формирование законодательства и его толкование на основе принципов естественного права. Автором приводятся примеры проблем в законодательстве и его интерпретации в Европе в период Нового времени. Подчеркивается влияние европейских сторонников естественно-правовой теории на разрешение законодательных проблем с помощью толкования права. Распространение естественно-правовых воззрений способствует тому, что европейское законодательство и его толкование начинают основываться на приниипах справедливости и гуманизма.

Ключевые слова: теория естественного права, толкование правовых норм, Новое время, «платоническая кассачия», европейские правоведы, законодательные противоречия, принции справедливости, принцип гуманизма.

Научная специальность: 12.00.00 - юридические науки. 